\title{
Effects of dietary yeast inclusion and acute stress on post- prandial whole blood profiles of dorsal aorta-cannulated rainbow trout
}

\author{
David Huyben • Aleksandar Vidakovic • Andreas Nyman • \\ Markus Langeland • Torbjörn Lundh $\mathbb{D} \cdot$ Anders Kiessling
}

Received: 2 June 2016/Accepted: 21 September 2016/Published online: 27 September 2016

(C) The Author(s) 2016. This article is published with open access at Springerlink.com

\begin{abstract}
Yeast is a potential alternative to fish meal in diets for farmed fish, yet replacing more than $50 \%$ of fish meal results in reduced fish growth. In a 4-week experiment, 15 rainbow trout (Oncorhynchus mykiss) were cannulated and fed three diets each week: $30 \%$ fish meal as a control (FM); $60 \%$ replacement of fish meal protein, on a digestible basis, with Saccharomyces cerevisiae (SC); and $60 \%$ replacement with Wickerhamomyces anomalus and S. cerevisiae mix (WA). Blood was collected at 0, 3, 6, 12 and $24 \mathrm{~h}$ after feeding. In the final week, fish were exposed to a 1-min netting stressor to evaluate possible diet-stress interactions. Significant increases in $\mathrm{pH}, \mathrm{TCO}_{2}, \mathrm{HCO}_{3}$ and base excess were found after fish were fed the $\mathrm{SC}$ and WA diets compared with FM, which elevated blood alkaline tides. Yeast ingredients had lower buffering capacity and ash content than fish meal, which explained the increase in alkaline tides. In addition, fish fed the WA diet had significantly reduced erythrocyte area and fish fed SC and WA diets had increased mean corpuscular haemoglobin levels, indicating haemolytic anaemia. Higher levels of nucleic acid in yeast-based diets and potentially higher production of reactive oxygen species were suspected
\end{abstract}

D. Huyben - A. Vidakovic - A. Nyman .

M. Langeland · T. Lundh ( $\square) \cdot$ A. Kiessling

Department of Animal Nutrition and Management,

Swedish University of Agricultural Sciences, Box 7024,

75007 Uppsala, Sweden

e-mail: Torbjorn.Lundh@slu.se of damaging haemoglobin, which require replacement by smaller immature erythrocytes. Acute stress caused the expected rise in cortisol and glucose levels, but no interaction with diet was found. These results show that replacing $60 \%$ of fish meal protein with yeasts can induce haemolytic anaemia in rainbow trout, which may limit yeast inclusion in diets for farmed fish.

Keywords Rainbow trout · Yeast - Aquaculture · Dorsal aorta cannulation · Buffering capacity · Anaemia

\section{Introduction}

The aquaculture industry relies on fish meal and soy as major protein sources in diets for farmed fish; however, food demand and environmental costs have increased the need for ingredients of non-human interest (Tacon and Metian 2008; Naylor et al. 2009; FAO 2014). Yeast is a single cell protein (SCP) produced from fermentation of agricultural by-products and used in biofuel, brewery and baking processes, but rarely used as a protein source in human food (Ravindra 2000). In fish research, only a few studies have replaced soy and fish meal with yeasts, such as Saccharomyces cerevisiae, in diets for rainbow trout (Oncorhynchus mykiss) (Mahnken et al. 1980; Rumsey et al. 1992; Martin et al. 1993; Hauptman et al. 2014; Sealey et al. 2015). At most, 
Hauptman et al. (2014) successfully replaced $38 \%$ of fish meal (11\% of diet) with S. cerevisiae, but higher inclusion resulted in negative effects on weight gain and feed conversion even when feed intake and protein content were equal between fish meal- and yeast-based diets. More research is needed to explain the cause of reduced performance when fish are fed diets with high yeast inclusion.

Yeast and other SCP contain tenfold higher levels of nucleic acid, mainly from RNA, than meat and plant ingredients (Kihlberg 1972; Jonas et al. 2001). High quantities of nucleic acid cannot be safely metabolised by humans, as they result in high uric acid levels (hyperuricaemia) and gout (Waslien et al. 1970; Fox 1981). On the other hand, fish produce higher levels of uricase than other animals and are thought to be able to metabolise higher levels of nucleic acid in the diet without negative health effects (Kinsella et al. 1985; Rumsey et al. 1991; Andersen et al. 2006). In contrast, De la Higuera et al. (1981) and Sanchez-Muniz et al. (1982) found that feeding yeast, Wickerhamomyces anomalus, at $81 \%$ of the diet resulted in harmful levels of kidney uric acid and haemolytic anaemia in rainbow trout. Despite the ability of fish to degrade uric acid, catabolism of uric acid and its precursors generates hydrogen peroxide, a reactive oxygen species that can damage erythrocytes and cell membranes if levels of antioxidants are insufficient (Jain 1993; Berg et al. 2015). Hydrogen peroxide forms harmful hydroxyl radicals in the presence of iron or copper unless hydrogen peroxide is reduced to water by catalase or glutathione peroxidase, using glutathione as a substrate (Buetler et al. 2004). Therefore, an upper limit to dietary yeast inclusion may exist based on nucleic acid content and the anti-oxidation capacity of fish.

Aside from negative effects, yeast cell walls can be disrupted due to heat and pressure during feed extrusion (Nasseri et al. 2011) and release compounds, such as $\beta$-glucans and mannan-oligosaccharides, that have been shown in previous studies to stimulate immune function and reduce stress response in fish, as reviewed by Ring $\varnothing$ et al. (2011) and Meena et al. (2013). Those reviews concluded that feeding fish $\beta$ glucans and other immunostimulants typically results in increased respiratory burst and macrophage, lysozyme and leucocyte activities that boost resistance to infections and stress. The reviews also noted the lack of research on short-term and haematological effects of these compounds, especially when derived from intact yeast.

Dorsal aorta (DA) cannulation was first described by Conte et al. (1963) for the purpose of evaluating short-term variations in blood and plasma parameters in fish. Since then, multiple modifications to DA cannulation surgery and blood collection procedures have been made to reduce stress and evaluate voluntarily feeding fish (Soivio et al. 1975; Zohar 1980; Gamperl et al. 1994; Kiessling et al. 1995; Lo et al. 2003; Djordjevic et al. 2012). For example, combinations of anaesthetics, cannula abolishing sutures, reduced surgery time, tank design improvements and avoidance of secondary infections have improved DA cannulation (Zahl et al. 2012). Based on these advances, many studies have been able to sample blood from voluntarily feeding Atlantic salmon (Salmo salar) and evaluate short-term effects of feed ingredients and supplements (Hamre et al. 2001; Kiessling et al. 2003; Sunde et al. 2003; Olsen et al. 2005; Kiessling et al. 2006, 2009; Djordjevic et al. 2012). In contrast, most studies with DA-cannulated rainbow trout have used force-feeding (Ok et al. 2001; Karlsson et al. 2006; Eliason et al. 2010), which can stress and suppress metabolic pathways (Vijayan et al. 1991; Cooper and Wilson 2008). Hence, achieving voluntary feeding in DA-cannulated rainbow trout is essential to evaluate short-term effects of diet and stress on blood physiology.

The main objective of this study was to determine the effects of feeding high levels of yeast in the diet on whole blood parameters of DA-cannulated rainbow trout. A secondary objective was to distinguish between diet and stress effects of feeding yeasts and inducing an acute stressor on DA-cannulated rainbow trout.

\section{Materials and methods}

Fish and facilities

The experiment was carried out in the Aquatic Facility of the Veterinary Medicine and Animal Science Centre at the Swedish University of Agricultural Sciences (Uppsala, Sweden). Rainbow trout were acquired from a commercial producer, Vilstena fiskodling AB (Fjärdhundra, Sweden), and raised in groups in 200-L oval tanks. The groups were reduced periodically to one fish per tank that weighed $849 \pm 199 \mathrm{~g}$ (mean $\pm \mathrm{SD})$. Each 
tank was equipped with a partial shade $(80 \times 20 \mathrm{~cm})$, LED light and water flow at a rate of approximately $5 \mathrm{~L} \mathrm{~min}^{-1}$ (illustrated in Fig. 1). The combination of shade, light and water outlet positioned the fish voluntarily beside a collection port ( $5 \mathrm{~cm}$ diameter), which permitted undisturbed sampling. The tank system was flow-through and sourced with municipal freshwater that was analysed for dissolved oxygen (10.4 \pm $\left.0.7 \mathrm{mg} \mathrm{L}^{-1}\right)$, temperature $\left(14.7 \pm 0.2^{\circ} \mathrm{C}\right)$ and $\mathrm{pH}$ $(8.09 \pm 0.05)$ on a weekly basis. Fish were acclimatised to a 14:10 light cycle (lights on at 08:00) in order to collect 0 - and 12-h samples and were fed a commercial diet for at least 5-day post-surgery prior to the beginning of the trial. The present study was performed in compliance with laws and regulations on the use of animals for research purposes in Sweden, which is overseen by the Swedish Board of Agriculture (permit reference C74-14).

Dorsal aorta cannulation procedure

The DA cannulation was performed according to Soivio et al. (1975), with modifications devised by Kiessling et al. (1995), (2003) and Djordjevic et al.
(2012). In brief, each fish was sedated with $1 \mathrm{mg} \mathrm{L}^{-1}$ metomidate (Aquacalm, Western Chemical Inc., Ferndale, USA) according to Kreiberg and Powell (1991), placed in an aerated bath and anesthetised with $80 \mathrm{mg} \mathrm{L}^{-1}$ tricaine methane sulphonate (MS222; Finquel, Scan Aqua AS, Ånes, Norway) buffered with sodium bicarbonate to prevent $\mathrm{pH}$ changes. The anesthetised fish was transferred to a surgery bath that recirculated $60 \mathrm{mg} \mathrm{L}^{-1}$ buffered MS222 over the gills of the fish to maintain anaesthesia. Local anaesthetics of $0.1 \mathrm{~mL}$ lidocaine with adrenaline $\left(20 \mathrm{mg} \mathrm{mL}^{-1}\right.$; Xylocaine $^{\circledR}$, AstraZeneca, Södertälje, Sweden) were injected into the proximal roof of the mouth at the snout incision site, and $0.1 \mathrm{~mL}$ lidocaine without adrenaline $\left(5 \mu \mathrm{g} \mathrm{mL}^{-1}\right.$; Haukeland Sykehusapotek, Bergen, Norway) was injected into the distal roof near the dorsal aorta incision site. A hole was punctured through the snout with a sterile needle in order to insert a 4-cm piece of 180 polyethylene (PE) tubing to act as a stopper. A $100-\mathrm{cm}$ piece of $90 \mathrm{PE}$ tubing was heated to make a bulb $5 \mathrm{~cm}$ from the end to prevent the cannula from dislodging. The tip was narrowed and two microscopic holes were cut out to prevent the cannula from clogging. The cannula was heparinised
Fig. 1 Illustration of the tank design where the position of the light, shade and water outlet directed the dorsal aorta-cannulated rainbow trout adjacent to a sampling port for undisturbed blood collection

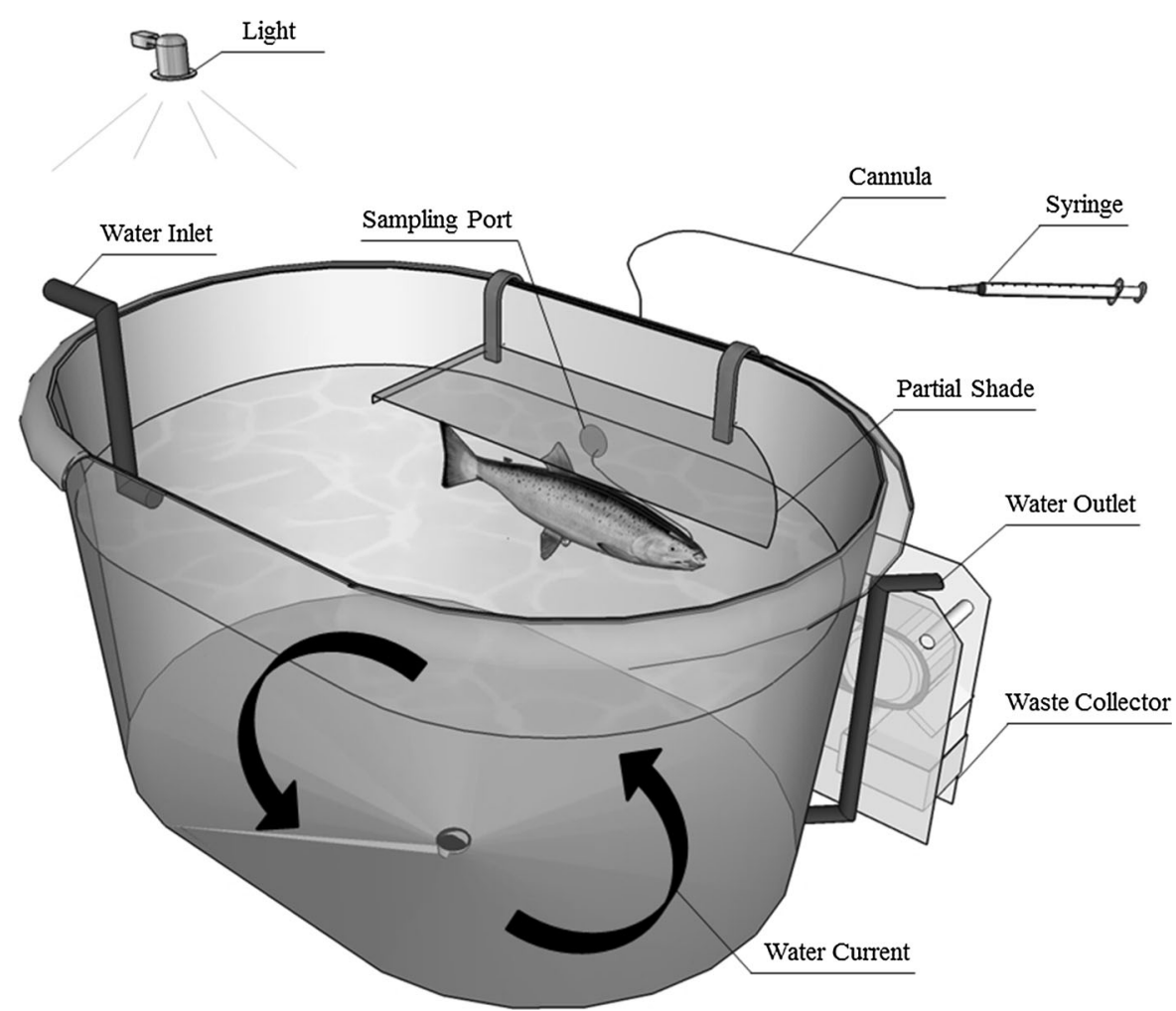


with 150 IU Na-heparin (LEO Pharma AS, Ballerup, Denmark) in saline $(0.9 \% \mathrm{NaCl})$ and then inserted into the DA of the fish via a guide wire after making an incision between the first and second set of gill arches. The cannula was drawn through the larger tubing previously inserted in the snout, injected with heparinsaline solution and the end was heat-sealed. An 80-cm piece of $180 \mathrm{PE}$ tubing was added to the cannula exterior to prevent damage from fish bites. Each fish was weighed after the surgical procedure and returned to the tank after gently spreading mucus from untouched skin to any affected areas of the fish to reduce the risk of infection. Each fish was gently guided around the tank to increase water flow over the gills and reduce recovery time. All fish resumed feeding within hours after surgery.

Diets and feeding

In total, 15 DA-cannulated fish were fed a control diet of $30 \%$ fishmeal (FM) and two test diets of yeasts: $S$. cerevisiae (SC) or a 70:30 mix of W. anomalus and $S$. cerevisiae (WA). In the SC and WA diets, $60 \%$ of fish meal protein was replaced with yeast protein to achieve $380 \mathrm{~g} \mathrm{~kg}^{-1}$ digestible protein (dry matter; DM) based on 95 and $86 \%$ digestibility coefficients for fish meal and yeast (NRC 2011; Langeland et al. 2016; Vidaković 2015). The diets were produced by extrusion at the Natural Resources Institute Finland (Laukaa, Finland) with a twin-screw extruder (3 mm die, BC-45 model, Clextral, Creusot Loir, France). Extruded pellets were air-dried overnight at $60^{\circ} \mathrm{C}$ and then sprayed with lipids using a vacuum coater (Pegasus PG-10VC, Dinnissen, Sevenum, Netherlands). For diet and proximate composition, see Table 1.

Each diet was analysed for crude protein $(\% \mathrm{~N} \times 6.25)$ using a Kjeltec 2020 digester and 2400 analyser (FOSS Analytical A/S, Hilleröd, Denmark) according to the Kjeldahl method (Nordic Committee on Food Analysis 1976), crude lipids using a Soxtec HT 1043 extractor (FOSS Analytical A/S, Hilleröd, Denmark) without acid hydrolysis according to the manufacturer (ANKOM Technology, Macedon, NY, USA), gross energy using a Parr 6300 isoperibol calorimeter (Parr Instrument Company, Moline, IL, USA) and nutrient detergent fibre according to the Amylase Neutral Detergent method (Mertens 2002). Diets and test ingredients were analysed for ash using
Table 1 Composition of the fish meal control diet (FM), a diet with $60 \%$ of fish meal replaced with Saccharomyces cerevisiae yeast (SC) and a diet with $60 \%$ of fish meal replaced with Wickerhamomyces anomalus and S. cerevisiae yeast (WA)

\begin{tabular}{|c|c|c|c|}
\hline & \multicolumn{3}{|l|}{ Diet } \\
\hline & FM & $\mathrm{SC}$ & WA \\
\hline \multicolumn{4}{|l|}{ Ingredients ( $\mathrm{g} \mathrm{kg}^{-1}$ as-is basis) } \\
\hline Fish meal $^{\mathrm{a}}$ & 300 & 120 & 120 \\
\hline S. cerevisiae yeast ${ }^{\mathrm{b}}$ & - & 321 & - \\
\hline W. anomalus/S. cerevisiae yeast $\mathrm{t}^{\mathrm{c}}$ & - & - & 355 \\
\hline Soy protein concentrate & 135 & 135 & 135 \\
\hline Wheat gluten & 120 & 120 & 120 \\
\hline Wheat starch & 100 & 10 & 0 \\
\hline Wheat meal & 60 & 60 & 60 \\
\hline Fish oil & 110 & 125 & 124 \\
\hline Rapeseed oil & 50 & 50 & 50 \\
\hline Titanium oxide & 5 & 5 & 5 \\
\hline Mineral-vitamin premix & 15 & 15 & 15 \\
\hline Monocalcium phosphate & 10 & 10 & 10 \\
\hline Cellulose & 93 & 24 & 0 \\
\hline L-methionine & 2 & 5 & 6 \\
\hline \multicolumn{4}{|c|}{ Proximate composition ( $\mathrm{g} \mathrm{kg}^{-1} \mathrm{DM}$ basis) } \\
\hline Dry matter $(\%)$ & 92 & 91 & 93 \\
\hline Crude protein ${ }^{\mathrm{d}}$ & 425 & 454 & 463 \\
\hline Crude lipid & 196 & 203 & 186 \\
\hline Gross energy $\left(\mathrm{MJ} \mathrm{kg}^{-1}\right)$ & 24 & 24 & 24 \\
\hline Neutral detergent fibre & 114 & 45 & 25 \\
\hline Ash & 68 & 63 & 62 \\
\hline
\end{tabular}

Modified from Vidaković (2015)

${ }^{a}$ Low-temperature dried Icelandic capelin meal (Rasioagro Ltd, Rasio, Finland); $90 \%$ dry matter; $710 \mathrm{~g} \mathrm{~kg}^{-1}$ crude protein; $117 \mathrm{~g} \mathrm{~kg}^{-1}$ crude lipid; $80 \mathrm{~g} \mathrm{~kg}^{-1}$ ash

b Dried yeast meal (Jästerbolaget AB, Uppsala, Sweden); $94 \%$ dry matter; $435 \mathrm{~g} \mathrm{~kg}^{-1}$ crude protein; $9 \mathrm{~g} \mathrm{~kg}^{-1}$ crude lipid; $58 \mathrm{~g} \mathrm{~kg}^{-1}$ ash; $78 \mathrm{~g} \mathrm{~kg}^{-1}$ nucleic acids

${ }^{c}$ Dried yeast meal with 70:30 W. anomalus to $S$. cerevisiae (Jästerbolaget AB, Uppsala, Sweden); $93 \%$ dry matter; $391 \mathrm{~g} \mathrm{~kg}^{-1}$ crude protein; $8 \mathrm{~g} \mathrm{~kg}^{-1}$ crude lipid; $65 \mathrm{~g} \mathrm{~kg}^{-1}$ ash; $76 \mathrm{~g} \mathrm{~kg}^{-1}$ nucleic acids

${ }^{\mathrm{d}}$ Diets balanced on a digestible protein content of $390 \mathrm{~g} \mathrm{~kg}^{-1}$

an incinerator at $550{ }^{\circ} \mathrm{C}$ for $3 \mathrm{~h}$ and buffering capacity by titrating $1 \mathrm{~g}$ with $0.1 \mathrm{M}$ lactic acid until the $\mathrm{pH}$ stabilised at 4.0 for 10 min (McDonald Henderson 1962). Yeast ingredients were analysed for total nucleic acids (TNA) using a sonicator at $20 \mathrm{Wm}^{-2}$ for $3 \mathrm{~min}$ in $0.5 \mathrm{~N}$ perchloric acid and measuring 
absorbance at $260 \mathrm{~nm} \quad\left(\mathrm{TNA}=\mathrm{OD}_{260 \mathrm{~nm}} \times 45.5\right)$ (Zachleder 1984).

Five fish per diet were fed at $1 \%$ body weight (BW) via automatic belt feeders (Hølland teknologi, Sandnes, Norway) once per day (i.e. 10:00 to 11:00) in a $3 \times 3$ randomised, cross-over design for 3 weeks. Feed waste from each tank was collected continuously using belt collectors (Hølland teknologi, Sandnes, Norway), weighed daily and pooled weekly. Feed and feed waste were analysed for DM content after drying at $103{ }^{\circ} \mathrm{C}$ for $16 \mathrm{~h}$ and then used to calculate feed intake: (Feed Fed DM - (Feed Waste DM/Recovery))/Feed DM, where recovery is the percentage of feed recovered after collection, according to Helland et al. (1996). Blood samples from fish with feed intake less than $0.2 \% \mathrm{BW}$ day $^{-1}$ were considered non-representative and rejected.

Blood sampling and stress procedures

Blood samples were taken from the cannula of each fish at 0 (30-60 min before feeding), 3, 6, 12 and $24 \mathrm{~h}$ after feeding on the 7th day of each week. In brief, the freefloating cannula was gently drawn through the collection port on the side of the tank using a thin hook. The cannula was cut, and the saline and first $0.1 \mathrm{~mL}$ of blood was discarded. Using a new heparinised syringe, $0.35 \mathrm{~mL}$ of blood was withdrawn from the cannula and then replaced with saline containing $150 \mathrm{IU}$ Na-heparin before heat sealing and returning the cannula to the tank. After whole blood analyses (below), samples were immediately centrifuged at $500 \mathrm{~g}$ for $3 \mathrm{~min}$ and the plasma was transferred to cryotubes, stored at $-20{ }^{\circ} \mathrm{C}$ and later transferred to a $-80{ }^{\circ} \mathrm{C}$ freezer.

To test for diet-stress interactions, blood samples were collected from fish fed for a fourth week on the same diet as in week three and then exposed to an acute stressor. Fish were removed from the water, held in a net beside the tank for $1 \mathrm{~min}$ and then returned. Fish swimming behaviour was monitored and showed that feed regurgitation was negligible, as the stress was induced $30 \mathrm{~min}$ after feeding to minimise vomiting (i.e. at 11:30). The first sample collected after netting occurred at 3-h postprandium or 30-min post-stress (i.e. 12:00).

\section{Blood and plasma analyses}

To determine effects on blood electrolytes and gases, blood was injected into EC8+ cassettes inserted into an i-STAT portable analyser (i-STAT Corporation,
East Windsor, NJ, USA) that measured sodium ( $\mathrm{Na}$, potassium $(\mathrm{K})$, glucose, $\mathrm{pH}$, partial carbon dioxide $\left(\mathrm{PCO}_{2}\right)$, total carbon dioxide $\left(\mathrm{TCO}_{2}\right)$, bicarbonate $\left(\mathrm{HCO}_{3}\right)$, base excess (BE) and haemoglobin $(\mathrm{Hb})$. Previous studies have validated i-STAT analyses against conventional methodologies for different fish species (Harrenstien et al. 2005; Harter et al. 2014).

To determine effects on erythrocytes, microcapillary tubes of blood were centrifuged at 12,000 $\mathrm{g}$ for $5 \mathrm{~min}$ and haematocrit (Hct) and leucocrit (Lct) levels were measured using linear and microscopic rulers. Red blood cells (RBC) were counted at $400 \times$ magnification in five $1 \mathrm{~mm}^{2}$ squares within a Bürker haemocytometer (Glaswarenfabrik Karl Hecht GmbH \& Co KG, Sondheim, Germany) after 1:20 dilution with Turk's solution (Stoskopf 1993). Erythrocyte area was measured from blood smears that were fixed and stained with methanol and Giemsa (Vázquez and Guerrero 2007). Four images at $400 \times$ magnification were taken from the periphery of the smear, and 10 random erythrocytes were automatically measured using NIS Elements Basic Research software (Nikon Instruments Europe BV, Amsterdam, Netherlands). Lastly, erythrocyte indices were calculated based on mean corpuscular volume $(\mathrm{MCV}=\mathrm{Hct} /$ $\mathrm{RBC} \times 10)$ mean corpuscular haemoglobin $(\mathrm{MCH}=\mathrm{Hb} / \mathrm{RBC} \times 10)$ and mean corpuscular haemoglobin concentration $(\mathrm{MCHC}=\mathrm{Hb} / \mathrm{Hct} \times 100)($ Stoskopf 1993).

As a stress indicator, cortisol was analysed from plasma using 96-well, multi-species ELISA kits (DetectX@), Arbor Assays, Ann Arbor, MI, USA) at $1: 25$ and 1:100 dilutions with assay buffer for unstressed and stressed fish. Ten plasma samples from unstressed and stressed samples were cross-referenced between the ELISA and RIA methods for cortisol and produced a covariance of $8.6 \pm 2.6 \%$ (mean $\pm \mathrm{SE}$ ).

Statistical analyses

Data were analysed using Linear Mixed Effects models (Bates et al. 2015) with $\mathrm{R}^{\circledR}$ version 3.2.2 software (R-Core-Team 2015). Fixed effects included in the models were diet, sampling time, feed intake $(\%$ BW day $^{-1}$ ) and fish weight, determined to be significant using ANOVA. In addition, the following terms were included in the models: random effects of fish and week to account for individual variation, interaction between diet and hour to account for hourly variation in blood parameters, and a correlation 
between hour and fish-week to account for repeated sampling. To determine diet-stress effects, unstressed fish from week 3 were compared with stressed fish from week 4 fed the same diet. Significant diet and stress effects were determined using post hoc Least Square Means tests (Lenth 2014) with Tukey adjustment for pair-wise comparisons. Differences between buffering capacity and ash content were determined using paired Student's $t$ test. Standardised residuals of all models were tested for normality by normal probability plots, $p<0.05$ was considered statistically significant, and $p<0.15$ was considered a tendency.

\section{Results}

In 4 weeks, fish achieved a mean weight gain of $161 \pm 107 \mathrm{~g}$ or $19 \pm 12 \%$ (mean $\pm \mathrm{SD}$ ) and fish fed diets FM, SC and WA achieved similar mean feed intakes of $0.84 \pm 0.22, \quad 0.89 \pm 0.23$ and $0.81 \pm$ $0.24 \% \mathrm{BW}$ day $^{-1}(p=0.589)$. For fish with feed intakes less than $0.2 \% \mathrm{BW}_{\text {day }}{ }^{-1}, 14$ out of 60 blood samples were excluded from analyses. There were no mortalities; however, five fish were replaced due to non-functioning cannulas.

Electrolyte, blood gases and $\mathrm{pH}$ analyses

Levels of $\mathrm{pH}, \mathrm{TCO}_{2}, \mathrm{HCO}_{3}$ and $\mathrm{BE}$ increased significantly in fish fed both yeast-based diets compared with fish fed the FM diet (Table 2; Fig. 2). The highest measured levels of $\mathrm{pH}, \mathrm{TCO}_{2}, \mathrm{HCO}_{3}$ and $\mathrm{BE}$ occurred at the first post-prandial sample $(3 \mathrm{~h})$, whereas $\mathrm{Na}$ and $\mathrm{PCO}_{2}$ levels did not change significantly over time. Glucose and $\mathrm{K}$ showed different post-prandial profiles between diets, as the highest values were at 6 and $0 \mathrm{~h}$ (continually decreased) for fish fed the FM diet, while the highest values were later (i.e. 12 and $3 \mathrm{~h}$ ) for the SC and WA diets. Fish fed yeast-based diets showed a tendency for an increase in $\mathrm{K}$ compared with fish fed the FM diet. Acid titration and ashing of the test ingredients showed that buffering capacity and ash content of fish meal were at least twofold higher than those of both yeasts (Fig. 3).

Haemotological analyses

Levels of Hct, Lct, RBC and Hb were not significantly different between diets and reached their lowest values at 12 or 24 h post-prandium (Table 3). No differences were observed for erythrocyte indices, except for $\mathrm{MCH}$ levels between fish fed the FM and WA diets, while there was a tendency for an increase in fish fed the SC and FM diets (Table 3; Fig. 2). Erythrocyte size was not significantly different between all diets, although area decreased significantly between 0 and $12 \mathrm{~h}$ samples in fish fed the WA diet (Table 3).

\section{Acute stress response}

Whole blood parameters and plasma cortisol concentration showed no significant differences between stressed fish fed the FM and yeast diets, and therefore values from fish fed all three diets were pooled to compare stressed and non-stressed fish. In contrast to unstressed fish, levels of $\mathrm{pH}, \mathrm{TCO}_{2}, \mathrm{HCO}_{3}$ and $\mathrm{BE}$ decreased significantly in stressed fish, with the lowest levels occurring at $0.5 \mathrm{~h}$ post-stress (Table 4). In addition, Hct and Lct were highest at $3.5 \mathrm{~h}$ post-stress, whereas consistent decreases over time were observed for unstressed fish. Lastly, significant increases in cortisol and glucose occurred at 0.5 and $3.5 \mathrm{~h}$ poststress, with cortisol concentration increasing more than 20-fold (Fig. 5).

\section{Discussion}

\section{Buffering capacity}

Significantly increased levels of blood $\mathrm{pH}, \mathrm{TCO}_{2}$, $\mathrm{HCO}_{3}$ and $\mathrm{BE}$ in fish fed the SC and WA diets (Table 2) indicated that the yeast diets induced higher alkaline tides than the FM diet. Alkaline tide is caused by efflux of $\mathrm{HCO}_{3}$ into the blood to prevent alkalinisation of the parietal cells after secretion of $\mathrm{HCl}$ into the stomach lumen during digestion (Niv and Fraser 2002). Bucking and Wood (2008) and Cooper and Wilson (2008) found similar increases in $\mathrm{pH}, \mathrm{HCO}_{3}$ and $\mathrm{BE}$ in DA-cannulated rainbow trout fed diets based on fish meal and suggested that high buffering capacity of fish meal influenced alkaline tide. Fish meal has been shown to have one of the highest buffering capacities among feedstuffs, and this characteristic has been correlated to high cation and ash content (Jasaitis et al. 1987; Lević et al. 2005; Montañez-Valdez 
Table 2 Electrolyte and gas values (mean \pm SE) in blood sampled from rainbow trout before and after they were fed diets containing fish meal (FM; $n=12)$, Saccharomyces cerevisiae yeast (SC; $n=9$ ) or Wickerhamomyces anomalus and $S$. cerevisiae yeast (WA; $n=13$ )

\begin{tabular}{|c|c|c|c|c|c|c|c|}
\hline \multirow[t]{2}{*}{ Variable } & \multirow[t]{2}{*}{ Diet } & \multicolumn{5}{|c|}{ Time after feeding $(\mathrm{h})^{\mathrm{a}}$} & \multirow[t]{2}{*}{$p$ value $^{\mathrm{b}}$} \\
\hline & & 0 & 3 & 6 & 12 & 24 & \\
\hline \multicolumn{8}{|l|}{ Electrolytes } \\
\hline \multirow[t]{3}{*}{$\mathrm{Na}\left(\mathrm{mmol} \mathrm{L}{ }^{-1}\right)$} & FM & $151.7 \pm 0.5$ & $151.5 \pm 0.6$ & $151.5 \pm 0.5$ & $151.6 \pm 0.6$ & $151.2 \pm 0.6$ & \\
\hline & $\mathrm{SC}$ & $150.3 \pm 0.5$ & $150.2 \pm 0.6$ & $150.2 \pm 0.4$ & $150.1 \pm 0.6$ & $150.6 \pm 0.4$ & 0.179 \\
\hline & WA & $151.0 \pm 0.4$ & $150.5 \pm 0.5$ & $150.5 \pm 0.7$ & $150.6 \pm 0.6$ & $150.9 \pm 0.8$ & 0.169 \\
\hline \multirow[t]{3}{*}{$\mathrm{K}\left(\mathrm{mmol} \mathrm{L}{ }^{-1}\right)$} & FM & $2.81 \pm 0.10 \mathrm{a}$ & $2.74 \pm 0.12 \mathrm{ab}$ & $2.59 \pm 0.08 \mathrm{ab}$ & $2.52 \pm 0.08 b$ & $2.56 \pm 0.09 \mathrm{ab}$ & \\
\hline & $\mathrm{SC}$ & $2.80 \pm 0.07 \mathrm{ab}$ & $3.04 \pm 0.12 b$ & $2.97 \pm 0.09 \mathrm{ab}$ & $2.73 \pm 0.09 a$ & $2.88 \pm 0.10 \mathrm{ab}$ & 0.076 \\
\hline & WA & $2.83 \pm 0.10 \mathrm{ab}$ & $3.01 \pm 0.09 \mathrm{~b}$ & $2.79 \pm 0.10 \mathrm{ab}$ & $2.63 \pm 0.10 \mathrm{a}$ & $2.78 \pm 0.11 \mathrm{ab}$ & 0.136 \\
\hline \multirow{3}{*}{$\begin{array}{l}\text { Glucose } \\
\quad\left(\mathrm{mmol} \mathrm{L}^{-1}\right)\end{array}$} & FM & $3.43 \pm 0.12 \mathrm{ab}$ & $4.08 \pm 0.21 \mathrm{c}$ & $4.33 \pm 0.26 \mathrm{c}$ & $4.01 \pm 0.26 \mathrm{~b}$ & $3.40 \pm 0.21 \mathrm{a}$ & \\
\hline & $\mathrm{SC}$ & $3.24 \pm 0.09 \mathrm{a}$ & $3.91 \pm 0.15 \mathrm{a}$ & $4.08 \pm 0.18 b$ & $4.31 \pm 0.32 b$ & $3.31 \pm 0.16 \mathrm{a}$ & 0.449 \\
\hline & WA & $3.23 \pm 0.11 \mathrm{a}$ & $3.77 \pm 0.01 \mathrm{ab}$ & $4.30 \pm 0.15 b c$ & $4.66 \pm 0.29 c$ & $3.15 \pm 0.12 \mathrm{a}$ & 0.934 \\
\hline \multirow[t]{3}{*}{$\mathrm{pH}$} & FM & $7.79 \pm 0.02 \mathrm{a}$ & $7.89 \pm 0.02 b$ & $7.83 \pm 0.01 \mathrm{ab}$ & $7.80 \pm 0.02 \mathrm{a}$ & $7.84 \pm 0.01 \mathrm{ab}$ & \\
\hline & $\mathrm{SC}$ & $7.83 \pm 0.02 \mathrm{a}$ & $7.92 \pm 0.02 b$ & $7.89 \pm 0.02 \mathrm{ab}$ & $7.86 \pm 0.02 \mathrm{ab}$ & $7.84 \pm 0.02 \mathrm{ab}$ & 0.048 \\
\hline & WA & $7.81 \pm 0.02 \mathrm{a}$ & $7.97 \pm 0.02 \mathrm{c}$ & $7.91 \pm 0.02 b$ & $7.87 \pm 0.02 \mathrm{ab}$ & $7.84 \pm 0.02 \mathrm{ab}$ & 0.001 \\
\hline \multicolumn{8}{|l|}{ Blood gases } \\
\hline \multirow[t]{3}{*}{$\mathrm{pCO}_{2}(\mathrm{mmHg})$} & FM & $5.9 \pm 0.1$ & $5.6 \pm 0.1$ & $5.8 \pm 0.1$ & $5.7 \pm 0.1$ & $5.6 \pm 0.1$ & \\
\hline & $\mathrm{SC}$ & $5.7 \pm 0.1$ & $5.9 \pm 0.2$ & $5.8 \pm 0.1$ & $5.9 \pm 0.1$ & $5.8 \pm 0.1$ & 0.843 \\
\hline & WA & $5.7 \pm 0.1$ & $5.6 \pm 0.1$ & $5.9 \pm 0.1$ & $5.7 \pm 0.2$ & $5.6 \pm 0.2$ & 0.971 \\
\hline \multirow[t]{3}{*}{$\mathrm{TCO}_{2}\left(\mathrm{mmol} \mathrm{L}^{-1}\right)$} & FM & $9.2 \pm 0.3$ & $11.0 \pm 0.5$ & $9.8 \pm 0.4$ & $9.1 \pm 0.4$ & $9.6 \pm 0.3$ & \\
\hline & $\mathrm{SC}$ & $9.7 \pm 0.5 \mathrm{a}$ & $12.4 \pm 0.9 b$ & $11.2 \pm 0.4 \mathrm{ab}$ & $10.8 \pm 0.5 \mathrm{ab}$ & $10.1 \pm 0.4 \mathrm{ab}$ & 0.028 \\
\hline & WA & $9.3 \pm 0.4 \mathrm{a}$ & $13.1 \pm 0.7 \mathrm{c}$ & $12.2 \pm 0.6 b c$ & $10.5 \pm 0.4 \mathrm{ab}$ & $9.8 \pm 0.3 \mathrm{a}$ & 0.001 \\
\hline \multirow[t]{3}{*}{$\mathrm{HCO}_{3}\left(\mathrm{mmol} \mathrm{L}^{-1}\right)$} & FM & $9.0 \pm 0.3$ & $10.9 \pm 0.5$ & $9.7 \pm 0.4$ & $8.9 \pm 0.4$ & $9.4 \pm 0.3$ & \\
\hline & $\mathrm{SC}$ & $9.5 \pm 0.5 \mathrm{a}$ & $12.2 \pm 0.8 b$ & $11.0 \pm 0.4 \mathrm{ab}$ & $10.6 \pm 0.5 \mathrm{ab}$ & $9.9 \pm 0.4 \mathrm{ab}$ & 0.028 \\
\hline & WA & $9.1 \pm 0.4 \mathrm{a}$ & $12.9 \pm 0.7 \mathrm{c}$ & $12.1 \pm 0.6 b$ & $10.3 \pm 0.4 \mathrm{ab}$ & $9.7 \pm 0.3 \mathrm{a}$ & 0.001 \\
\hline \multirow[t]{3}{*}{$\mathrm{BE}\left(\mathrm{mmol} \mathrm{L}^{-1}\right)$} & FM & $-11.8 \pm 0.6 \mathrm{a}$ & $-8.9 \pm 0.8 b$ & $-11.0 \pm 0.5 \mathrm{ab}$ & $-12.1 \pm 0.5 \mathrm{a}$ & $-11.1 \pm 0.4 \mathrm{ab}$ & \\
\hline & $\mathrm{SC}$ & $-10.9 \pm 0.7 \mathrm{a}$ & $-7.0 \pm 1.1 \mathrm{~b}$ & $-8.7 \pm 0.6 \mathrm{ab}$ & $-9.5 \pm 0.6 \mathrm{ab}$ & $-10.6 \pm 0.6 a$ & 0.020 \\
\hline & WA & $-11.5 \pm 0.5 a$ & $-5.8 \pm 1.0 \mathrm{c}$ & $-7.3 \pm 0.9 b c$ & $-9.8 \pm 0.6 a b$ & $-10.8 \pm 0.6 a$ & 0.001 \\
\hline
\end{tabular}

$\mathrm{Na}$ sodium, $\mathrm{K}$ potassium, $\mathrm{pCO}_{2}$ partial carbon dioxide, $\mathrm{TCO}_{2}$ total carbon dioxide, $\mathrm{HCO}_{3}$ bicarbonate, $\mathrm{BE}$ base excess

${ }^{a}$ Values within variable and diet followed by different lower case letters differ significantly $(p<0.05)$

b $P$ values for each mean variable of either the SC or WA diet compared with the FM diet based on linear mixed effects models that included diet, time, feed intake and weight as fixed effects and fish and week as random effects

et al. 2013). The present study confirmed that fish meal had more than twofold higher levels of ash and buffering capacity compared with both yeast ingredients (Fig. 3). Lower buffering capacity has been shown to have beneficial effects on protein metabolism and intestinal microbiota due to increased stomach pH (Eckel et al. 1992; Gabert and Sauer 1994). A study by our research group on yeastinduced changes to intestinal $\mathrm{pH}$ and microbiota is ongoing.

\section{Erythrocyte size}

Fish fed the WA diet had significantly smaller erythrocytes between 0 and $12 \mathrm{~h}$ after feeding (Table 3), which is indicative of haemolytic anaemia (Jain 1993). In fish, damage to erythrocytes results in increased production and replacement with smaller immature erythrocytes to compensate for losses in oxygen transport (Stoskopf 1993; Clauss et al. 2008; Hrubec and Smith 2010). Sanchez-Muniz et al. (1982) 


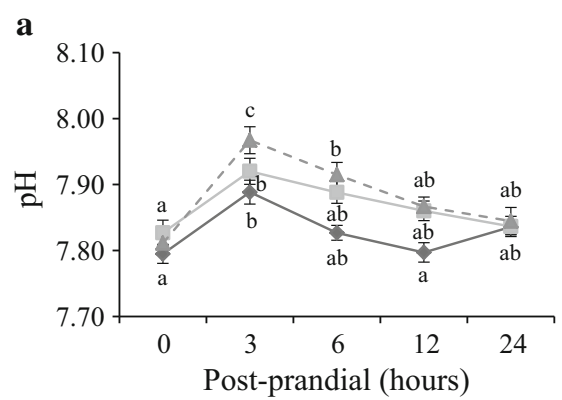

Fig. 2 Post-prandial whole blood values (mean $\pm \mathrm{SE}$ ) of a $\mathrm{pH}$ and b red blood cell (RBC) size in rainbow trout fed diets containing fish meal (FM, filled diamond), Saccharomyces cerevisiae yeast (SC, filled square) and Wickerhamomyces

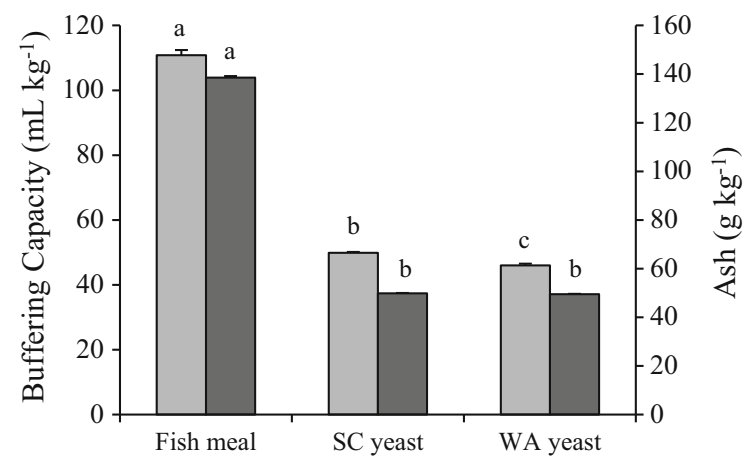

Fig. 3 Buffering capacity (light grey) and ash content (dark grey) on $\mathrm{a} \mathrm{kg}^{-1} \mathrm{DM}$ basis of the fish meal, Saccharomyces cerevisiae yeast (SC) and Wickerhamomyces anomalus and $S$. cerevisiae yeast (WA) ingredients. Values for each parameter followed by different lower case letters differ significantly $(p<0.05)$

found that rainbow trout fed diets containing $81 \% \mathrm{~W}$. anomalus had reduced erythrocyte size and lowered peroxidase activity compared with fish fed a fish mealbased diet. In fish and other monogastrics, catabolism of high levels of purine nucleotides, such as oxidation of xanthine and uric acid, has been shown to produce high levels of hydrogen peroxide that result in erythrocyte damage (Clifford and Story 1976; Goldenberg 1977; Bontemps et al. 1986; Rumsey et al. 1992; Berg et al. 2015). Glutathione and glutathione peroxidase are responsible for diminishing toxic effects of hydrogen peroxide, but if the glutathione concentration and/ or the peroxidase activity is insufficient that can lead to oxidation of haemoglobin to methaemoglobin, Heinz body formation and eventual haemolysis (Mills and Randall 1958; Berg et al. 2015) (see Fig. 4). In addition to deficiencies in

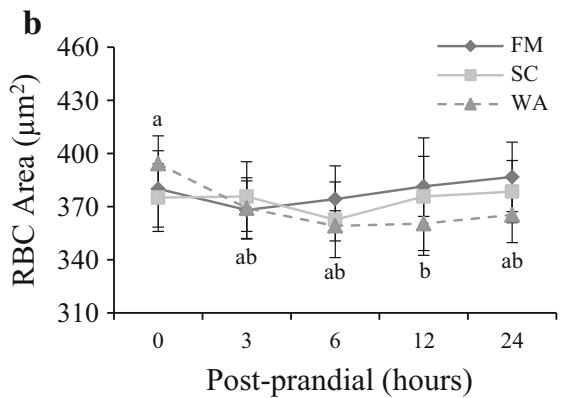

anomalus and S. cerevisiae yeast (WA, filled triangle). Values within diet followed by different lower case letters differ significantly $(p<0.05)$

glutathione, deficiencies in NADPH or other components of the pentose phosphate pathway required to maintain glutathione levels can lead to decreased haemoglobin protection (Mills and Randall 1958; Berg et al. 2015). Therefore, the haemolysis observed in fish fed yeast diets in the present study suggests that the level of purine nucleotides was too high to be safely metabolised by rainbow trout (Fig. 4).

Haemolytic anaemia can have long-term effects on physiology, such as chronic fatigue, due to insufficient oxygen transport and increased erythropoiesis (Jain 1993). Anaemia effects may explain the reduced fish growth observed in previous studies feeding yeast to rainbow trout, in which above $40 \%$ of fish meal (30\% of the diet) was replaced (Rumsey et al. 1991; Hauptman et al. 2014; Vidaković 2015). Rumsey et al. (1992) showed diets that contained up to $4.1 \%$ yeast-derived nucleic acid (50\% yeast inclusion) did not reduce fish growth, but diets containing $1.5 \%$ adenosine, a purine nucleotide, resulted in decreased growth of rainbow trout. In the present study, yeast ingredients of $S$. cerevisiae and $W$. anomalus mix contributed 2.5 and $2.3 \%$ nucleic acid to SC and WA diets (Table 1), but the level of adenosine was not determined. Interestingly, blood alkalinisation and glucose reductions have been shown to increase purine nucleotide catabolism in vitro (Bontemps et al. 1986; Van den Berghe et al. 1988), whereas both conditions occurred in fish fed yeast diets in the present study and suggests that toxic effects of purine catabolism may have been elevated. However, more research is required to establish the correlation and limit between dietary levels of yeast-derived purine nucleotides with haemolysis and reduced growth for rainbow trout. 
Table 3 Haematology, red blood cell indices and hormone values (mean $\pm \mathrm{SE}$ ) in blood sampled from rainbow trout before and after they were fed diets containing fish meal (FM; $n=12)$, Saccharomyces cerevisiae yeast (SC; $n=9)$ or Wickerhamomyces anomalus and S. cerevisiae yeast (WA; $n=13$ )

\begin{tabular}{|c|c|c|c|c|c|c|c|}
\hline \multirow[t]{2}{*}{ Variable } & \multirow[t]{2}{*}{ Diet } & \multicolumn{5}{|c|}{ Time after feeding $(h)^{\mathrm{a}}$} & \multirow[t]{2}{*}{$p$ value $^{\mathrm{b}}$} \\
\hline & & 0 & 3 & 6 & 12 & 24 & \\
\hline \multicolumn{8}{|l|}{ Haematology } \\
\hline \multirow[t]{3}{*}{ Hct $(\%)$} & $\mathrm{FM}$ & $19.8 \pm 0.9 \mathrm{ab}$ & $21.1 \pm 1.2 \mathrm{a}$ & $18.3 \pm 0.7 b$ & $17.6 \pm 0.8 b$ & $17.5 \pm 0.8 b$ & \\
\hline & $\mathrm{SC}$ & $20.2 \pm 0.8$ & $21.2 \pm 1.2$ & $19.3 \pm 0.9$ & $18.5 \pm 1.5$ & $18.6 \pm 1.2$ & 0.920 \\
\hline & WA & $21.7 \pm 1.4 \mathrm{a}$ & $21.0 \pm 0.9 \mathrm{ab}$ & $19.2 \pm 1.1 \mathrm{ab}$ & $19.3 \pm 1.2 \mathrm{ab}$ & $18.4 \pm 0.7 b$ & 0.681 \\
\hline \multirow[t]{3}{*}{ Lct $(\%)$} & FM & $1.1 \pm 0.05 \mathrm{a}$ & $0.9 \pm 0.06 \mathrm{ab}$ & $0.9 \pm 0.06 \mathrm{ab}$ & $0.8 \pm 0.07 b$ & $1.0 \pm 0.08 \mathrm{a}$ & \\
\hline & $\mathrm{SC}$ & $0.9 \pm 0.1$ & $1.0 \pm 0.1$ & $0.9 \pm 0.1$ & $0.7 \pm 0.1$ & $0.8 \pm 0.1$ & 0.855 \\
\hline & WA & $1.0 \pm 0.1$ & $0.9 \pm 0.1$ & $0.9 \pm 0.1$ & $0.8 \pm 0.1$ & $0.9 \pm 0.1$ & 0.982 \\
\hline \multirow[t]{3}{*}{$\mathrm{Hb}\left(\mathrm{g} \mathrm{dL}^{-1}\right)$} & $\mathrm{FM}$ & $5.8 \pm 0.2$ & $5.6 \pm 0.3$ & $5.4 \pm 0.2$ & $5.0 \pm 0.2$ & $5.1 \pm 0.2$ & \\
\hline & $\mathrm{SC}$ & $6.1 \pm 0.4$ & $6.0 \pm 0.3$ & $5.8 \pm 0.3$ & $5.7 \pm 0.5$ & $5.3 \pm 0.5$ & 0.602 \\
\hline & WA & $6.2 \pm 0.4 \mathrm{a}$ & $6.3 \pm 0.2 \mathrm{a}$ & $5.8 \pm 0.3 \mathrm{ab}$ & $5.8 \pm 0.4 \mathrm{ab}$ & $5.1 \pm 0.2 b$ & 0.351 \\
\hline \multirow[t]{3}{*}{$\operatorname{RBC}\left(10^{6}\right.$ cells $\left.\mu \mathrm{L}^{-1}\right)$} & FM & $0.78 \pm 0.06$ & $0.77 \pm 0.04$ & $0.72 \pm 0.04$ & $0.70 \pm 0.04$ & $0.68 \pm 0.03$ & \\
\hline & $\mathrm{SC}$ & $0.74 \pm 0.05$ & $0.77 \pm 0.06$ & $0.74 \pm 0.05$ & $0.74 \pm 0.06$ & $0.65 \pm 0.04$ & 0.838 \\
\hline & WA & $0.70 \pm 0.05$ & $0.73 \pm 0.04$ & $0.75 \pm 0.04$ & $0.72 \pm 0.05$ & $0.68 \pm 0.04$ & 0.614 \\
\hline \multirow[t]{3}{*}{$\mathrm{RBC}$ area $\left(\mu \mathrm{m}^{2}\right)$} & $\mathrm{FM}$ & $380.0 \pm 21.6$ & $368.1 \pm 16.4$ & $374.3 \pm 18.7$ & $381.4 \pm 16.9$ & $386.8 \pm 19.6$ & \\
\hline & $\mathrm{SC}$ & $375.1 \pm 19.0$ & $375.7 \pm 19.7$ & $362.6 \pm 21.4$ & $375.7 \pm 33.1$ & $378.5 \pm 17.5$ & 0.921 \\
\hline & WA & $394.3 \pm 15.7 \mathrm{a}$ & $369.1 \pm 17.1 \mathrm{ab}$ & $359.2 \pm 8.5 \mathrm{ab}$ & $360.4 \pm 15.2 b$ & $365.3 \pm 15.6 a b$ & 0.999 \\
\hline \multicolumn{8}{|l|}{ Erythrocyte Indices } \\
\hline \multirow[t]{3}{*}{$\operatorname{MCV}\left(\mathrm{fL} \mathrm{cell}{ }^{-1}\right)$} & FM & $267.2 \pm 19.1$ & $296.9 \pm 42.1$ & $261.9 \pm 15.9$ & $260.8 \pm 17.9$ & $260.2 \pm 13.9$ & \\
\hline & $\mathrm{SC}$ & $282.5 \pm 16.9$ & $291.9 \pm 30.8$ & $273.8 \pm 24.3$ & $253.6 \pm 14.0$ & $294.0 \pm 20.5$ & 0.704 \\
\hline & WA & $325.5 \pm 22.6$ & $289.9 \pm 8.7$ & $259.0 \pm 9.8$ & $272.1 \pm 9.3$ & $278.1 \pm 11.5$ & 0.476 \\
\hline \multirow[t]{3}{*}{$\mathrm{MCH}\left(\mathrm{pg} \mathrm{cell}{ }^{-1}\right)$} & $\mathrm{FM}$ & $78.6 \pm 5.4$ & $75.6 \pm 6.1$ & $77.5 \pm 4.9$ & $74.3 \pm 6.4$ & $75.4 \pm 3.8$ & \\
\hline & $\mathrm{SC}$ & $85.3 \pm 5.7$ & $82.6 \pm 9.7$ & $82.6 \pm 7.9$ & $77.6 \pm 5.3$ & $84.2 \pm 9.0$ & 0.108 \\
\hline & WA & $93.9 \pm 7.6$ & $87.5 \pm 3.2$ & $78.7 \pm 3.0$ & $81.6 \pm 3.7$ & $78.5 \pm 4.5$ & 0.029 \\
\hline \multirow[t]{3}{*}{$\operatorname{MCHC}\left(\mathrm{g} \mathrm{dL}^{-1}\right)$} & $\mathrm{FM}$ & $29.7 \pm 1.0$ & $26.7 \pm 1.0$ & $29.6 \pm 0.5$ & $28.3 \pm 0.7$ & $29.3 \pm 1.3$ & \\
\hline & $\mathrm{SC}$ & $30.2 \pm 0.8$ & $28.1 \pm 0.4$ & $30.1 \pm 0.6$ & $30.6 \pm 1.3$ & $28.1 \pm 1.2$ & 0.489 \\
\hline & WA & $28.7 \pm 0.7$ & $30.2 \pm 0.8$ & $30.5 \pm 0.7$ & $29.9 \pm 0.5$ & $28.2 \pm 0.9$ & 0.214 \\
\hline \multicolumn{8}{|l|}{ Hormones } \\
\hline \multirow[t]{3}{*}{ Cortisol (ng mL ${ }^{-1}$ ) } & FM & $3.1 \pm 0.9$ & $3.5 \pm 0.9$ & $3.4 \pm 1.1$ & $6.4 \pm 2.2$ & $3.5 \pm 0.9$ & \\
\hline & $\mathrm{SC}$ & $2.6 \pm 0.6 \mathrm{a}$ & $1.8 \pm 0.6 \mathrm{a}$ & $2.4 \pm 0.6 \mathrm{a}$ & $7.1 \pm 1.4 b$ & $2.9 \pm 0.7 \mathrm{a}$ & 0.895 \\
\hline & WA & $3.3 \pm 0.6$ & $3.6 \pm 1.0$ & $4.0 \pm 1.4$ & $6.6 \pm 1.7$ & $3.1 \pm 0.6$ & 0.967 \\
\hline
\end{tabular}

$H c t$ haematocrit, Lct leucocrit, $H b$ haemoglobin, $R B C$ red blood cells, $M C V$ mean corpuscular volume, $M C H$ mean corpuscular haemoglobin, $M C H C$ mean corpuscular haemoglobin concentration

${ }^{a}$ Values within variable and diet followed by different lower case letters differ significantly $(p<0.05)$

b $P$ values for each mean variable of either the SC or WA diet compared with the FM diet based on linear mixed effects models that included diet, time, feed intake and weight as fixed effects and fish and week as random effects

Erythrocyte haemoglobin

In addition to erythrocyte size, there was a significant increase in MCH levels, an indicator of hyperchromic anaemia (Stoskopf 1993), in fish fed the WA diet and a tendency for an increase in fish fed the SC diet (Table 3). In contrast, Sanchez-Muniz et al. (1979) found decreased MCH levels in fish fed a W. anomalus diet, indicating hypochromic anaemia. However, oxidation of haemoglobin to methaemoglobin and 
Table 4 Whole blood and plasma cortisol values (mean \pm SE) in rainbow trout sampled before and after exposure to a 1-min netting stressor (Pooled diets; $n=12$ )

\begin{tabular}{|c|c|c|c|c|c|c|}
\hline \multirow[t]{2}{*}{ Variable } & \multicolumn{5}{|c|}{ Time after stress $(h)^{a}$} & \multirow[t]{2}{*}{$p$ value $^{\mathrm{b}}$} \\
\hline & 0 & 0.5 & 3.5 & 9.5 & 21.5 & \\
\hline Glucose $\left(\mathrm{mmol} \mathrm{L}{ }^{-1}\right)$ & $3.2 \pm 0.1 \mathrm{a}$ & $5.0 \pm 0.2 b c$ & $5.6 \pm 0.5 \mathrm{c}$ & $5.9 \pm 0.5 \mathrm{c}$ & $4.4 \pm 0.4 \mathrm{ab}$ & 0.012 \\
\hline $\mathrm{pH}$ & $7.79 \pm 0.01 \mathrm{a}$ & $7.62 \pm 0.03 b$ & $8.00 \pm 0.03 c$ & $7.93 \pm 0.01 \mathrm{~cd}$ & $7.84 \pm 0.02 \mathrm{ad}$ & 0.032 \\
\hline Hct $(\%)$ & $19.7 \pm 0.8 \mathrm{ab}$ & $23.4 \pm 0.9 \mathrm{c}$ & $20.0 \pm 0.7 \mathrm{bc}$ & $18.1 \pm 1.3 b$ & $16.7 \pm 0.7 \mathrm{a}$ & 0.399 \\
\hline Lct $(\%)$ & $1.05 \pm 0.09 \mathrm{a}$ & $1.15 \pm 0.10 \mathrm{ab}$ & $0.83 \pm 0.05 \mathrm{c}$ & $0.77 \pm 0.04 \mathrm{c}$ & $0.99 \pm 0.08 \mathrm{ac}$ & 0.674 \\
\hline $\mathrm{TCO}_{2}\left(\mathrm{mmol} \mathrm{L}^{-1}\right)$ & $8.6 \pm 0.3 \mathrm{a}$ & $5.9 \pm 0.3 b$ & $13.7 \pm 1.0 \mathrm{c}$ & $11.7 \pm 0.4 \mathrm{~cd}$ & $9.9 \pm 0.4 \mathrm{ad}$ & 0.038 \\
\hline $\mathrm{HCO}_{3}\left(\mathrm{mmol} \mathrm{L}^{-1}\right)$ & $8.5 \pm 0.3 \mathrm{a}$ & $5.7 \pm 0.3 b$ & $13.6 \pm 1.0 \mathrm{c}$ & $11.6 \pm 0.3 \mathrm{~cd}$ & $9.8 \pm 0.4 \mathrm{ad}$ & 0.038 \\
\hline $\mathrm{BE}\left(\mathrm{mmol} \mathrm{L}{ }^{-1}\right)$ & $-12.3 \pm 0.4 \mathrm{a}$ & $-17.3 \pm 0.6 b$ & $-5.0 \pm 1.3 \mathrm{c}$ & $-8.0 \pm 0.5 \mathrm{~cd}$ & $-10.7 \pm 0.6 \mathrm{ad}$ & 0.028 \\
\hline Cortisol (ng mL $\left.{ }^{-1}\right)$ & $6.4 \pm 1.5 \mathrm{a}$ & $129.2 \pm 27.3 b$ & $38.5 \pm 18.2 \mathrm{a}$ & $15.0 \pm 2.7 \mathrm{a}$ & $6.2 \pm 1.3 \mathrm{a}$ & 0.014 \\
\hline
\end{tabular}

$\mathrm{Hct}$ haematocrit, Lct leucocrit, $\mathrm{TCO}_{2}$ total carbon dioxide, $\mathrm{HCO}_{3}$ bicarbonate, $\mathrm{BE}$ base excess

${ }^{a}$ Values within variable followed by different lower case letters differ significantly $(p<0.05)$

b $P$ values for each mean variable of either the SC or WA diet compared with the FM diet based on linear mixed effects models that included diet, time, feed intake and weight as fixed effects and fish and week as random effects

Fig. 4 Simplified diagram of purine nucleotide catabolism in fish, resulting in production of hydrogen peroxide $\left(\mathrm{H}_{2} \mathrm{O}_{2}\right)$ that can be: (1) reduced to $\mathrm{H}_{2} \mathrm{O}$ by glutathione peroxidase given adequate glutathione $\mathrm{SH}$ :SS ratio maintained by the pentose phosphate pathway, or (2) used to oxidise haemoglobin to methaemoglobin molecules that link to form Heinz bodies, modified from Sanchez-Muniz et al. (1982) and Berg et al. (2015)

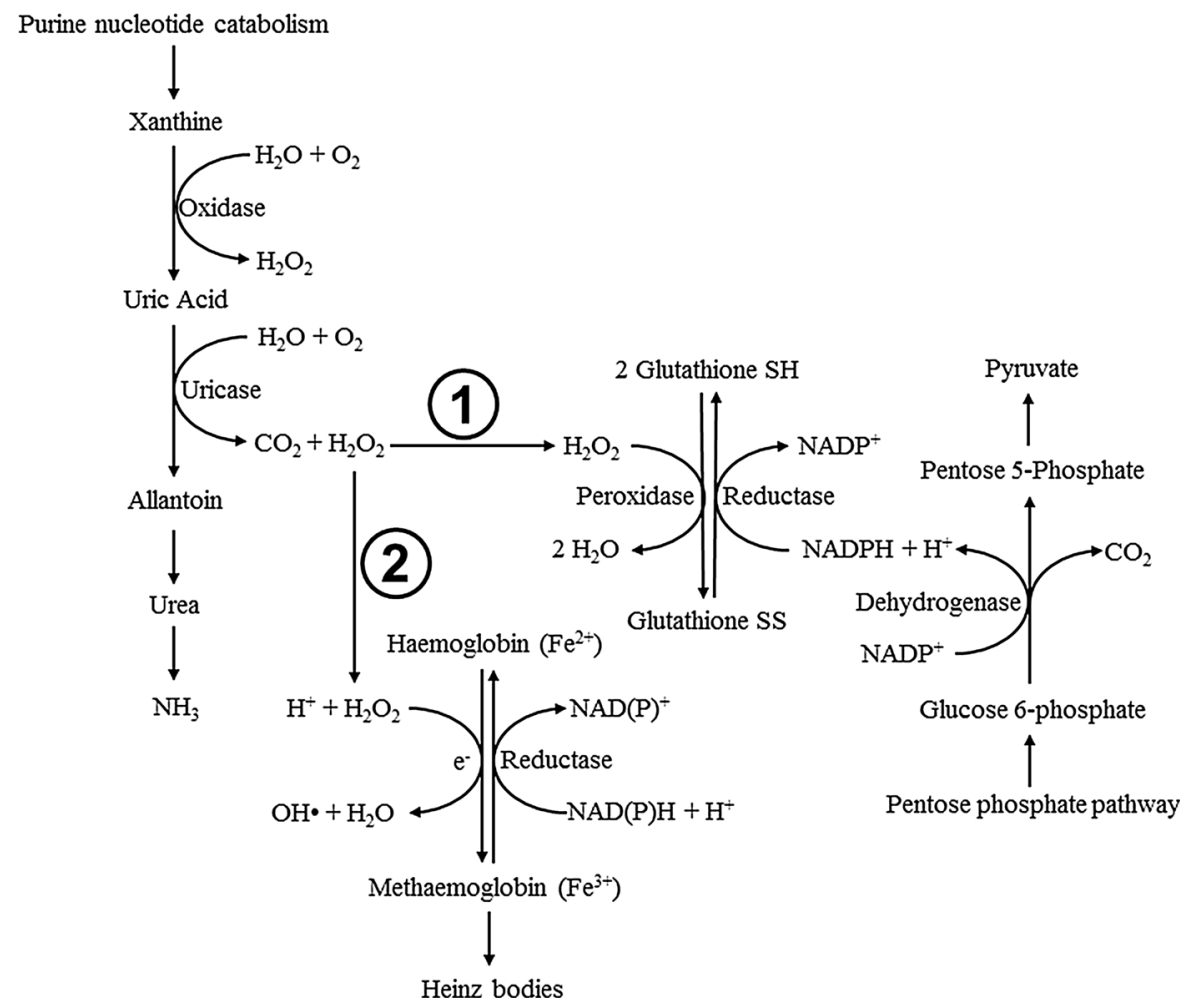

subsequent formation of Heinz bodies can result in erroneous elevations in MCH and MCHC values (Jain 1993). In comparison with previous studies (Miller et al. 1983; Řehulka et al. 2004), both MCH and $\mathrm{MCHC}$ values in the present study were equal to or above the 99th percentile for rainbow trout (Table 3). However, the i-STAT method for haemoglobin determination and the large fish used in the present study may have increased $\mathrm{MCH}$ and $\mathrm{MCHC}$ values, despite the difference between diets. Microcytic anaemia is 

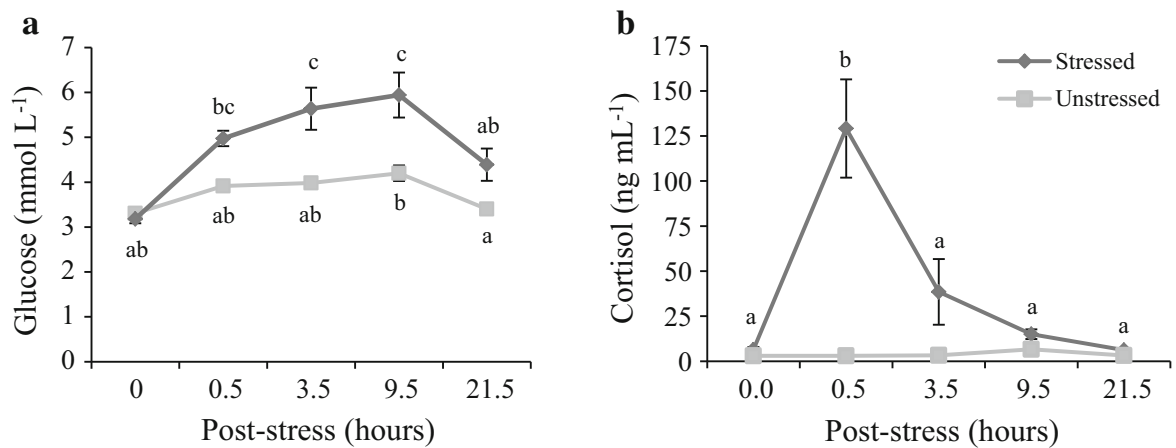

Fig. 5 Post-prandial whole blood values (mean \pm SE) of a glucose, and b cortisol in unstressed (filled square) and stressed (filled diamond) rainbow trout. Values for unstressed or stressed fish followed by different lower case letters differ significantly $(p<0.05)$

typically not associated with hyperchromic conditions since smaller immature erythrocytes should not contain higher levels of haemoglobin (Jain 1993). Higher inclusion of yeast in the WA diet than in the SC diet (Table 1) may have increased the effect of haemolysis on fish, although the non-significant reduction in erythrocyte size and tendency for an increase in $\mathrm{MCH}$ in fish fed the SC diet (Table 3) suggest that the SC diet induced haemolysis to a lesser extent. Therefore, the higher MCH levels in the present study may have been artificially increased by formation of Heinz bodies due to haemolysis.

Acute stress response

Fish showed significantly increased cortisol and glucose levels between 0.5 and $9.5 \mathrm{~h}$ post-stress (Fig. 5), but no differences were found between diets. Elevations in cortisol and glucose are used as primary and secondary indicators of stress in fish (Barton and Iwama 1991). In unstressed fish, plasma cortisol levels increased significantly at 12 -h post-prandium for all diets (Table 3 ), which can be explained by diurnal cycling based on circadian rhythm, as shown previously (Holloway et al. 1994; Reddy and Leatherland 2003). Increases in Hct and Lct have also been used as secondary indicators of stress in fish studies (Anderson 1990; Barton and Iwama 1991). In the present study, levels of Hct significantly increased 0.5 -h post-stress and then both Hct and Lct levels continually decreased similar to unstressed fish (Table 3 and 4). The slight Hct increase may be a reflection of the low intensity stressor, while continual reductions in Hct and Lct for unstressed fish have been found in previous studies, which attributed the decrease to haemodilution as an effect of repeated blood sampling (Soivio et al.
1972, 1975; Bry and Zohar 1980; Deng et al. 2000). In contrast to $\mathrm{Hct}$, the levels of $\mathrm{pH}$ and $\mathrm{HCO}_{3}$ significantly decreased immediately after stress (Table 4). This is in agreement with findings in previous studies, which attributed the decrease to elevated gill ventilation and anaerobic processes (Jones and Randall 1979; Turner et al. 1983). Lastly, no effects of the yeast diets were observed on whole blood and cortisol parameters of fish, although more research should be performed on extracted yeast compounds, e.g. $\beta$-glucans. Therefore, yeast-based diets did not reduce the acute stress response of fish, but on the other hand these novel protein sources did not induce further stress.

Voluntary feeding in fish

To the best of our knowledge, this study was the first to examine the effects of diet on whole blood and cortisol parameters in DA-cannulated rainbow trout following voluntary feeding. In contrast with previous studies (Ok et al. 2001; Karlsson et al. 2006; Eliason et al. 2010), force-feeding was avoided in the present study in order to negate stress effects on fish physiology and diet metabolism (Vijayan et al. 1991). For example, Cooper and Wilson (2008) found that blood $\mathrm{pH}$ and $\mathrm{HCO}_{3}$ were twofold higher in rainbow trout after force-feeding than after voluntary feeding. The success in achieving voluntary feeding in the present study may be attributable to several months of tank acclimatisation with step-wise reductions in fish stocking density, although this was not tested. By eliminating the stress from force-feeding, this study may provide a more realistic scenario of post-prandial whole blood and cortisol parameters in rainbow trout. 
Replacing $60 \%$ of fish meal on a digestible protein basis with $S$. cerevisiae and $W$. anomalus mix significantly affected whole blood parameters in rainbow trout, but no interaction between diet and stress was found following exposure to an acute stressor. After feeding, yeast diets induced higher alkaline tides in fish due to lower dietary ash content and consequently lower buffering capacity of yeast ingredients compared with fish meal. In addition, yeast diets induced haemolytic anaemia, which resulted in smaller erythrocytes and artificial elevations in $\mathrm{MCH}$, especially for fish fed the WA diet. These results support previous suggestions that catabolism of high levels of nucleic acids produce reactive oxygen species that can overwhelm anti-oxidation pathways and damage erythrocytes. Overall, this study demonstrated that replacing fish meal with yeasts in rainbow trout diets reduced feed buffering capacity and induced haemolytic anaemia. Reduced buffering capacity can be beneficial for feed metabolism, but the nucleic acid content could limit the level of yeast inclusion in fish diets. Reductions in nucleic acids, specifically purine nucleotides, may mitigate anaemia effects in rainbow trout fed diets with $60 \%$ replacement of fish meal with yeasts, though more research is needed to confirm this.

Acknowledgments Funding for this study was provided by FORMAS (Swedish Research Council for Environment, Agricultural Sciences and Spatial Planning; No. 223-2013297) and stipend funding from grants held by Professor Rich Moccia, University of Guelph, Canada. The authors are especially grateful to Rich Moccia, Jouni Vielma, Stefan Örn, Anna-Greta Haglund and Börje Ericson for their help and discussions and to Jästbolaget ${ }^{\circledR}$ for contributing the test ingredients.

Open Access This article is distributed under the terms of the Creative Commons Attribution 4.0 International License (http:// creativecommons.org/licenses/by/4.0/), which permits unrestricted use, distribution, and reproduction in any medium, provided you give appropriate credit to the original author(s) and the source, provide a link to the Creative Commons license, and indicate if changes were made.

\section{References}

Andersen $\emptyset$, Skugor S, Takle H, van Nes S, Grisdale-Helland B, Helland SJ, Terjesen BF (2006) Purine induced expression of urate oxidase and enzyme activity in Atlantic salmon (Salmo salar). FEBS J 273:2839-2850
Anderson DP (1990) Immunological indicators: effects of environmental stress on immune protection and disease outbreaks. In: American fisheries society symposium, pp 38-50

Barton BA, Iwama GK (1991) Physiological changes in fish from stress in aquaculture with emphasis on the response and effects of corticosteroids. Ann Rev Fish Dis 1:3-26

Bates D, Mächler M, Bolker B, Walker S (2015) Fitting linear mixed-effects models using lme4. J Stat Softw 67:1-48. doi:10.18637/jss.v067.i01

Berg JM, Tymoczko JL, Gatto GJ, Stryer L (2015) The calvin cycle and the pentose phosphate pathway. In: Biochemistry, 8th edn. W. H. Freeman \& Company, New York, USA, pp 589-616

Bontemps F, Van den Berghe G, Hers H (1986) Pathways of adenine nucleotide catabolism in erythrocytes. J Clin Invest 77:824

Bry C, Zohar Y (1980) Dorsal aorta catheterization in rainbow trout (Salmo gairdneri). II. Glucocorticoid levels, hematological data and resumption of feeding for five days after surgery. Reprod Nutr Dev 20:1825-1834

Bucking C, Wood CM (2008) The alkaline tide and ammonia excretion after voluntary feeding in freshwater rainbow trout. J Exp Biol 211:2533-2541

Buetler TM, Krauskopf A, Ruegg UT (2004) Role of superoxide as a signaling molecule. Physiology 19:120-123

Clauss TM, Dove AD, Arnold JE (2008) Hematologic disorders of fish. Vet Clin North Am Exot Anim Pract 11:445-462

Clifford AJ, Story DL (1976) Levels of purines in foods and their metabolic effects in rats. J Nutr 106:435-442

Conte FP, Wagner HH, Harris TO (1963) Measurement of blood volume in the fish (Salmo gairdneri gairdneri). Am J Physiol 205:533-540

Cooper C, Wilson R (2008) Post-prandial alkaline tide in freshwater rainbow trout: effects of meal anticipation on recovery from acid-base and ion regulatory disturbances. J Exp Biol 211:2542-2550

De la Higuera M, Sanchez-Muniz F, Mataix F, Varela G (1981) Nitrogen utilization by rainbow trout (Salmo gairdneri) fed on the yeast Hansenula anomala. Comp Biochem Physiol A Physiol 69:583-586

Deng D, Refstie S, Hemre G-I, Crocker C, Chen H, Cech J Jr, Hung S (2000) A new technique of feeding, repeated sampling of blood and continuous collection of urine in white sturgeon. Fish Physiol Biochem 22:191-197

Djordjevic B, Kristensen T, Overli O, Rosseland BO, Kiessling A (2012) Effect of nutritional status and sampling intensity on recovery after dorsal aorta cannulation in free-swimming Atlantic salmon (Salmo salar L.). Fish Physiol Biochem 38:259-272. doi:10.1007/s10695-009-9362-2

Eckel B, Kirchgessner M, Roth F (1992) Influence of formic acid on daily weight gain, feed intake, feed conversion rate and digestibility, 1: investigations about the nutritive efficacy of organic acids in the rearing of piglets. J Anim Physiol Anim Nutr 67:93-100

Eliason EJ, Djordjevic B, Trattner S, Pickova J, Karlsson A, Farrell AP, Kiessling AK (2010) The effect of hepatic passage on postprandial plasma lipid profile of rainbow trout (Oncorhynchus mykiss) after a single meal. Aquacult Nutr 16:536-543. doi:10.1111/j.1365-2095.2009.00693.x 
FAO (2014) The state of world fisheries and aquaculture 2014. United Nations Food and Agriculture Organization, Rome, p 62

Fox IH (1981) Metabolic basis for disorders of purine nucleotide degradation. Metabolism 30:616-634

Gabert V, Sauer W (1994) The effects of supplementing diets for weanling pigs with organic acids. A review. J Anim Feed Sci 3:73-87

Gamperl A, Vijayan M, Boutilier R (1994) Epinephrine, norepinephrine, and cortisol concentrations in cannulated seawater acclimated rainbow trout (Oncorhynchus mykiss) following black box confinement and epinephrine injection. J Fish Biol 45:313-324

Goldenberg H (1977) Organization of purine degradation in the liver of a teleost (carp; Cyprinus carpio L.). A study of its subcellular distribution. Mol Cell Biochem 16:17-21

Hamre K, Kolås K, Sandnes K, Julshamn K, Kiessling A (2001) Feed intake and absorption of lipid oxidation products in Atlantic salmon (Salmo salar) fed diets coated with oxidised fish oil. Fish Physiol Biochem 25:209-219. doi:10. 1023/a:1022257928437

Harrenstien LA, Tornquist SJ, Miller-Morgan TJ, Fodness BG, Clifford KE (2005) Evaluation of a point-of-care blood analyzer and determination of reference ranges for blood parameters in rockfish. J Am Vet Med Assoc 226:255-265

Harter TS, Shartau RB, Brauner CJ, Farrell AP (2014) Validation of the i-STAT system for the analysis of blood parameters in fish. Conserv Physiol 2:cou037. doi:10.1093/ conphys/cou037

Hauptman BS, Barrows FT, Block SS, Gaylord TG, Paterson JA, Rawles SD, Sealey WM (2014) Evaluation of grain distillers dried yeast as a fish meal substitute in practicaltype diets of juvenile rainbow trout, Oncorhynchus mykiss. Aquaculture 432:7-14. doi:10.1016/j.aquaculture.2014.03. 026

Helland S, Grisdale-Helland B, Nerland S (1996) A simple method for the measurement of daily feed intake of groups of fish in tanks. Aquaculture 139:157-163

Holloway A, Reddy P, Sheridan M, Leatherland J (1994) Diurnal rhythms of plasma growth hormone, somatostatin, thyroid hormones, cortisol and glucose concentrations in rainbow trout, Oncorhynchus mykiss, during progressive food deprivation. Biol Rhythm Res 25:415-432

Hrubec T, Smith S (2010) Hematology of fishes. In: Weiss D, Wardrop K (eds) Schalm's veterinary hematology, 6th edn. Wiley, Ames, pp 994-1003

Jain NC (1993) Hemolytic anemias of noninfectious origin. In: Mundorff G (ed) Essentials of veterinary hematology. Lea and Febiger, Malvern, pp 193-209

Jasaitis D, Wohlt J, Evans J (1987) Influence of feed ion content on buffering capacity of ruminant feedstuffs in vitro. J Dairy Sci 70:1391-1403

Jonas D et al (2001) Safety considerations of DNA in food. Ann Nutr Metab 45:235-254

Jones DR, Randall DJ (1979) The respiratory and circulatory systems during exercise. Fish Physiol 7:425-501

Karlsson A, Eliason EJ, Mydland LT, Farrell AP, Kiessling A (2006) Postprandial changes in plasma free amino acid levels obtained simultaneously from the hepatic portal vein and the dorsal aorta in rainbow trout (Oncorhynchus mykiss). J Exp Biol 209:4885-4894. doi:10.1242/jeb. 02597

Kiessling A, Dosanjh B, Higgs D, Deacon G, Rowshandeli N (1995) Dorsal aorta cannulation: a method to monitor changes in blood levels of astaxanthin in voluntarily feeding Atlantic salmon, Salmo salar L. Aquacult Nutr $1: 43-50$

Kiessling A, Olsen RE, Buttle L (2003) Given the same dietary carotenoid inclusion, Atlantic salmon, Salmo salar (L.) display higher blood levels of canthaxanthin than astaxanthin. Aquacult Nutr 9:253-261

Kiessling A, Dosanjh B, Koppe W, Higgs D (2006) Relationship between blood and muscle levels of astaxanthin in dorsal aorta cannulated Atlantic salmon. Aquaculture 254:653-657

Kiessling A, Johansson D, Zahl IH, Samuelsen OB (2009) Pharmacokinetics, plasma cortisol and effectiveness of benzocaine, MS-222 and isoeugenol measured in individual dorsal aorta-cannulated Atlantic salmon (Salmo salar) following bath administration. Aquaculture 286:301-308. doi:10.1016/j.aquaculture.2008.09.037

Kihlberg R (1972) The microbe as a source of food. Annu Rev Microbiol 26:427-466

Kinsella J, German B, Shetty J (1985) Uricase from fish liver: isolation and some properties. Comp Biochem Physiol B Comp Biochem 82:621-624

Kreiberg H, Powell J (1991) Metomidate sedation reduces handling stress in Chinook salmon. World Aquacult 22:58-59

Langeland M, Vidakovic A, Vielma J, Lindberg J, Kiessling A, Lundh T (2016) Digestibility of microbial and mussel meal for Arctic charr (Salvelinus alpinus) and Eurasian perch (Perca fluviatilis). Aquacult Nutr 22:485-495. doi:10. 1111/anu.12268

Lenth R (2014) Least-squares means: the R Package 1smeans. J Stat Software. doi:10.18637/jss.v069.i01

Lević J, Prodanović O, Sredanović S (2005) Understanding the buffering capacity in feedstuffs. Biotech Anim Husbandry 21:309-313

Lo W-Y, Chang C-F, Song Y-L (2003) Evaluation of dorsal aorta cannulation for immunological studies of grouper (Epinephelus malabaricus). Fish Shellfish Immunol 14:289-303. doi:10.1006/fsim.2002.0437

Mahnken CV, Spinelli J, Waknitz FW (1980) Evaluation of an alkane yeast (Candida sp.) as a substitute for fish meal in Oregon Moist Pellet: feeding trials with coho salmon (Oncorhynchus kisutch) and rainbow trout (Salmo gairdneri). Aquaculture 20:41-56

Martin AM, Goddard S, Bemibster P (1993) Production of Candida utilis biomass as aquaculture feed. J Sci Food Agric 61:363-370

McDonald Henderson P (1962) Buffering capacity of herbage samples as a factor in ensilage. J Sci Food Agric 13:395-400

Meena DK et al (2013) Beta-glucan: an ideal immunostimulant in aquaculture (a review). Fish Physiol Biochem 39:431-457. doi:10.1007/s10695-012-9710-5

Mertens DR (2002) Gravimetric determination of amylasetreated neutral detergent fiber in feeds with refluxing in beakers or crucibles: collaborative study. J AOAC Int $85: 1217-1240$ 
Miller WR, Hendricks AC, Cairns J Jr (1983) Normal ranges for diagnostically important hematological and blood chemistry characteristics of rainbow trout (Salmo gairdneri). Can J Fish Aquat Sci 40:420-425

Mills GC, Randall HP (1958) Hemoglobin catabolism II. The protection of hemoglobin from oxidative breakdown in the intact erythrocyte. J Biol Chem 232:589-598

Montañez-Valdez OD, Solano-Gama JdJ, Martínez-Tinajero JJ, Guerra-Medina CE, Ley de Coss A, Orozco-Hernandez R (2013) Buffering capacity of common feedstuffs used in ruminant diets. Revista Colombiana de Ciencias Pecuarias 26:37-41

Nasseri A, Rasoul-Amini S, Morowvat M, Ghasemi Y (2011) Single cell protein: production and process. Am J Food Tech 6:103-116

Naylor RL et al (2009) Feeding aquaculture in an era of finite resources. Proc Natl Acad Sci 106:15103-15110. doi:10. 1073/pnas.0905235106

Niv Y, Fraser GM (2002) The alkaline tide phenomenon. J Clin Gastroenterol 35:5-8

Nordic Committee on Food Analysis (1976) Determination in feeds and faeces according to Kjeldahl, No 6. In: NKML, Oslo, Norway

NRC (2011) Nutrient requirements of fish and shrimp. National Academy Press, Washington, DC

Ok IH, Bai S, Park GJ, Choi SM, Kim KW (2001) The patterns of plasma free amino acids after force feeding in rainbow trout Oncorhynchus mykiss (Walbaum) with and without dorsal aorta cannulation. Aquacult Res 32:70-75

Olsen RE, Kiessling A, Milley JE, Ross NW, Lall SP (2005) Effect of lipid source and bile salts in diet of Atlantic salmon, Salmo salar L., on astaxanthin blood levels. Aquaculture 250:804-812. doi:10.1016/j.aquaculture.2005.03. 013

Ravindra P (2000) Value-added food: single cell protein. Biotechnol Adv 18:459-479

R-Core-Team (2015) R: a language and environment for statistical computing, 3.2.2 edn. R Foundation for Statistical Computing, Vienna

Reddy P, Leatherland J (2003) Influences of photoperiod and alternate days of feeding on plasma growth hormone and thyroid hormone levels in juvenile rainbow trout. J Fish Biol 63:197-212

Řehulka J, Minařík B, Řehulková E (2004) Red blood cell indices of rainbow trout Oncorhynchus mykiss (Walbaum) in aquaculture. Aquacult Res 35:529-546

Ring $\varnothing$ E, Olsen RE, Vecino JLG, Wadsworth S (2011) Use of immunostimulants and nucleotides in aquaculture: a review. J Mar Sci Res Dev. doi:10.4172/2155-9910. 1000104

Rumsey G, Kinsella J, Shetty K, Hughes S (1991) Effect of high dietary concentrations of brewer's dried yeast on growth performance and liver uricase in rainbow trout $(\mathrm{On}$ corhynchus mykiss). Anim Feed Sci Technol 33:177-183

Rumsey GL, Winfree RA, Hughes SG (1992) Nutritional value of dietary nucleic acids and purine bases to rainbow trout (Oncorhynchus mykiss). Aquaculture 108:97-110

Sanchez-Muniz F, De La Higuera M, Mataix F, Varela G (1979) The yeast Hansenula anomala as a protein source for rainbow trout (Salmo gairdneri). hematological aspects. Comp Biochem Physiol A Physiol 63:153-157

Sanchez-Muniz F, de La Higuera M, Varela G (1982) Alterations of erythrocytes of the rainbow trout (Salmo gairdneri) by the use of Hansenula anomala yeast as sole protein source. Comp Biochem Physiol A Physiol 72:693-696

Sealey WM, O'Neill TJ, Peach JT, Gaylord TG, Barrows FT, Block SS (2015) Refining inclusion levels of grain distiller's dried yeast in commercial type and plant based diets for juvenile rainbow trout, Oncorhynchus mykiss. J World Aquacult Soc 46:434-444

Soivio A, Westman K, Nyholm K (1972) Improved method of dorsal aorta catheterization: haematological effects followed for three weeks in rainbow trout (Salmo gairdneri). Finn Fish Res 1:1-2

Soivio A, Nynolm K, Westman K (1975) A technique for repeated sampling of the blood of individual resting fish. J Exp Biol 63:207-217

Stoskopf M (1993) Clinical pathology. In: Stoskopf M (ed) Fish medicine. WB Saunders, Philadelphia, pp 113-131

Sunde J, Kiessling A, Higgs D, Opstvedt J, Venturini G, Rungruangsak-Torrissen K (2003) Evaluation of feed protein quality by measuring plasma free amino acids in Atlantic salmon (Salmo salar L.) after dorsal aorta cannulation. Aquacult Nutr 9:351-360

Tacon AGJ, Metian M (2008) Global overview on the use of fish meal and fish oil in industrially compounded aquafeeds: trends and future prospects. Aquaculture 285:146-158. doi:10.1016/j.aquaculture.2008.08.015

Turner J, Wood C, Clark D (1983) Lactate and proton dynamics in the rainbow trout (Salmo gairdneri). J Exp Biol 104:247-268

Van den Berghe G, Bontemps F, Vincent M-F (1988) Cytosolic purine $5^{\prime}$-nucleotidases of rat liver and human red blood cells: regulatory properties and role in AMP dephosphorylation. Adv Enzyme Regul 27:297-311

Vázquez GR, Guerrero G (2007) Characterization of blood cells and hematological parameters in Cichlasoma dimerus (Teleostei, Perciformes). Tissue Cell 39:151-160

Vidaković A (2015) Fungal and mussel protein sources in fish feed. Ph.D. Thesis, Acta Universitas Agriculture Sueciae No. 2015:90, Swedish University of Agricultural Sciences

Vijayan M, Ballantyne J, Leatherland J (1991) Cortisol-induced changes in some aspects of the intermediary metabolism of Salvelinus fontinalis. Gen Comp Endocrinol 82:476-486

Waslien CI, Calloway DH, Margen S, Costa F (1970) Uric acid levels in men fed algae and yeast as protein sources. J Food Sci 35:294-298

Zachleder V (1984) Optimization of nucleic acids assay in green and blue-green algae: extraction procedures and the lightactivated diphenylamine reaction for DNA. Arch Hydrobiol 67:313-328

Zahl IH, Samuelsen O, Kiessling A (2012) Anaesthesia of farmed fish: implications for welfare. Fish Physiol Biochem 38:201-218. doi:10.1007/s10695-011-9565-1

Zohar Y (1980) Dorsal aorta catheterization in rainbow trout (Salmo gairdneri), I: its validity in the study of blood gonadotropin patterns. Reprod Nutr Dev 20:1811-1823 